\title{
Customer Superstitions In the Accommodation Industry: A Demographic Analysis
}

\author{
NG, LEE KENG ${ }^{1}$, and TAMMY WEE ${ }^{2 *}$ \\ ${ }^{1}$ Hospitality Business Programme, Design and Specialised Businesses Cluster, \\ Singapore Institute of Technology. \\ ${ }^{2}$ School of Tourism and Hospitality Management, American University of Phnom Penh, Cambodia.
}

\begin{abstract}
This research project focused on the topic of superstitions which is widely prevalent but under-explored. Specifically, this study examined the effects of demographical variables (namely, gender, age, education, income, and religion) on 18 superstitious behaviours. An online survey was distributed using two non-probability sampling techniques: snowballing and voluntary response sampling. The data collection was done through known contacts and on a social media platform within online communities. The survey was open to participants who were at least 18 years old and fitted the other criterion of being guests at hotels, hostels, Airbnb, etc. A total of 126 usable responses was collected and analysed. Descriptive statistics and MANOVA results indicated that demographical variables did not have much effect on superstitious behaviours. Furthermore, the extent of superstitious behavioural displays was also not varied among respondents with different demographical profiles. In a challenging business landscape, it is relevant and important for the accommodation industry to have heightened awareness about guests' superstitions. Such knowledge can aid the operators in exhibiting extra cultural sensitivity and gracious respect towards their guests, generating more satisfaction and building loyalty.
\end{abstract}

\section{Introduction}

It is no overstatement that most people are at least a little superstitious, whether it is placing trust in auspicious numbers, knocking on wood for good luck, or believing that Friday the $13^{\text {th }}$ is an unlucky day (Diamond, 2017; Kramer \& Block, 2011). What is superstition? Researchers have different definitions for a concept that involves religion, numerical homonym, traditional customs, feng-shui, good luck charms, etc. (Huang \& Teng, 2009; Tobacyk \& Milford, 1983; Torgler, 2007).

CONTACT Tammy Wee tammieweeeegmail.com_ 9 School of Tourism and Hospitality Management, American University of Phnom Penh, Cambodia.

(C) 2021 The Author(s). Published by Enviro Research Publishers.

This is an Open Access article licensed under a Creative Commons license: Attribution 4.0 International (CC-BY).

Doi: http://dx.doi.org/10.12944/JBSFM.03.01-02.13 
KENG \& WEE, Journal of Business Strategy Finance and Management,

Vol. 03(1-2) 134-147 (2021)

Superstitions have endureddespite all the technological progress and dominance. Even if the superstitious beliefs do not make sense, people persist in letting the irrational beliefs continue to impact their thoughts, feelings, and behaviours (University of Chicago Booth School of Business, 2015). Superstitions give meaning to the random nature of luck; they have the appeal as a remedy for people to manage their fears, anxieties and hope (Hood, 2010; Mulvania, n.d.).

When people travel, they bring their superstitious traditions along with them (McCartney, 2013). The experiences of being in less familiar or unfamiliar environments could induce a fear of uncertainty and unknown risk (Reisinger \&Mavondo, 2005; Sun, 2014, Yusof, 2015). Hence, guests observe superstitions to have a sense of security, control and ease, especially when faced with unpredictable or inexplicable phenomena at the accommodation premises (Thio, 2015; Vaidyanathan et al., 2018).

While superstition has been examined in the contexts of business (Burakov, 2018; Raesita \& Mahadwartha, 2020; Simmons \& Robert, 2003; Wu et al., 2016), education (Abitov et al., 2018; Chakraborty, 2017; Undie \& Ushie, 2018), and even sports (Gmelch, 1972; Hagan et al., 2019; Jirásek, 2018), there is very limited academic study of superstitions in the accommodation industry (Pratt \& Kwan, 2019). There are only a couple of research papers that discussed how numerological superstitions affect the numbering and assigning of hotel floors and rooms (Pratt \& Kirillova, 2019; Pratt \& Kwan, 2019). There is no scholastic research that explored accommodation guests' range of superstitious beliefs and behaviours.

Thus, this study was designed to achieve two objectives to fill the gaps in literature: to examine the variety of superstitions that guests have when they stay at accommodations, and to understand how demographics might affect superstitions. The findings have apparent relevance for the accommodation industry's operators who could use the new knowledge to improve guests' experience and loyalty by respecting their superstitious beliefs and practices (eHotelier, 2019).

\section{Literature Review Demographical Variables}

Literature suggests that the antecedents of superstitions could include demographic factors such as gender, age, educational level, economic status and religion (Dag, 1999; Pratt \& Kirillova, 2019; Vaidyanathan et al., 2018; Vyse, 2014; Wolfradt, 1997).

Findings suggested that women generally tend to be more superstitious than men, ever since their predominant presence in religious events in feudal times (Valussi, 2020). Women are more probable to demonstrate superstitious behaviours such as wanting to change a 13th floor hotel room in order to have an inner calm and 'protect' themselves (Carroll, 2007; Huang \& Teng, 2009; Orenstein, 2002; Tobacyk \& Milford, 1983; Wiseman \& Watt, 2004; Yang et al., 2018).

Contrary to common guesses, younger people could be more prone to believing in superstitions (Torgler, 2007). Being younger, they could feel less certain about the future; they are more likely to adopt socially accepted behaviours so as to seek a sense of social belongingness (Gere \& Mac Donald, 2010; Orenstein, 2002; Torgler, 2007; Victor \& Yang, 2012). There is also a different view that there might be only a slight variation between the younger and the older individuals. For instance, Carroll's (2007) study showed that $12 \%$ of those aged between 18 to 49 years old, and $14 \%$ of those aged 50 years old and older were similarly bothered when assigned the $13^{\text {th }}$ floor of a hotel.

While some researchers found no association between superstition and educational level, other researchers claimed that individuals with a higher level of education are likely to be less superstitious (Aarnio \& Linderman, 2005; Barro \& McCleary, 2002; Mowen \& Carlson, 2003; Salter \& Routledge, 1971). This is because higher education typically includes knowledge and academic training about critical, logical thinking. The non-association between superstitions and high educational level could also be a result of social judgment since individuals with superstitious behaviours could be perceived 
by others as being uneducated, irrational, and incompetent (Case etal., 2004; Wang et al., 2015).

It was found that people with relative deprivation (i.e., worse off on some economic standard or lacking advantageous life situations) are more likely to use superstitions to give themselves the perceived control to cope with their higher psychological distress (Abrams et al., 1999; Burger, 1989; Rice, 2003; Smith et al., 2012; Stark \& Bainbridge, 1980).It was found that those in the lower social class or who were unemployed were more inclined to believe in the power of horoscopes and lucky charms (Torgler, 2007). For this study, monthly income was chosen as a variable instead of employment that was used by Pratt and Kirivolla (2019) as the respondents who were contacted via the non-probability sampling were most probably employed.

The relationship between religion and superstitions is a non-conclusive one. On one hand, some studies indicated that there is a positive relationship between religion and superstitions because both involve philosophical beliefs that resist the laws of science (Goode, 2000; MacDonald, 1995; Orenstein, 2002; Torgler, 2003). On the other hand, another set of findings suggested there is an inverse relationship between religion and the belief in paranormal phenomena (Ellis, 1988; Rice, 2003).People without religious affiliation were found to be more likely to believe the supernatural as compared to those who have religion. One key reason is that activities involving tarot cards and crystal power are specifically rejected by the church and some other religious establishments (Emmons \& Sobal, 1981; Goode, 2000; Zinnbauer et al., 1997).

\section{Types of Superstitions}

Whether superstitions are extreme or harmless, they are widely practised, based on online commentaries and news articles. The more frequently mentioned ones are discussed here and were incorporated into the online survey instrument. To begin with, it is uncommon to use 13 for the designations of rooms or floors in hotels. The elevator buttons may skip from 12 to 14 , or $12 \mathrm{~A}$ is used instead (De Lollis, 2007; eHotelier, 2019; Prakash, 2016). The other number that is avoided is 4 which is deemed ominous because it sounds like'death' in Mandarin and Chinese dialects (Diamond, 2017; Prakash, 2016; Romero, 2016).
One superstition requires guests to knock (up to three times) before entering the rooms. The knocking is supposed to courteously inform the spirits of guests' arrival, respectfully ask the spirits to depart, and leave the guests alone (eHotelier, 2019; Thio, 2015; Woon, 2019). Upon room entry, there is a series of superstition-driven behaviours: open all the curtains, open all the windows too, and switch on all the lights (Oei, 2013). All these are to let sunlight and fresh air (all positive energy) into the room and announce the guests' presence to any spirits (Yusof, 2015). Another belief cum behaviour upon room entry is to flush the toilet immediately. This is to flush away any negative energy and once again inform the spirits that someone has arrived (Oei, 2013; Silverman, 2017; Woon, 2019).

During the stay, it is recommended to place random belongings on all beds, be it luggage, clothes or toiletries. The other option is to simply mess up the bedding of any unoccupied bed so that the spirits would not claim the vacant bed for their use (eHotelier, 2019; Silverman, 2017; Thio, 2015; Woon, 2019; Yusof, 2015).However, random belongings do not include hats. This is because some think that evil spirits may dwell inside hats (Oei, 2013). It was also said that in Italy, doctors and priests on house calls would drop their hats on the sick or dying person's bed. Thus, if a hat is placed on the bed, the sleeper will be condemned to bad luck (Marchetti, 2020).

Regarding fittings in the room, there are a few misgivings about mirrors. Some cultures believe that it is bad luck to sleep facing a mirror as the mirror could sap away the positive energy in the room, deflect away good luck, or steal the sleeper's soul (Oei, 2013; Silverman, 2017; Woon, 2019; Yusof, 2015). There is an accompanying belief that the soul leaves the body at night while the individual is asleep. Hence, the soul may get confused by the reflection in the mirror and fail to return to the body (Thio, 2015).

To augment all the earlier actions of knocking, letting in the light, and flushing toilet, individuals could take extra measures by patting the pillows before going to bed. This serves to send a repeated signal to the spirits that the bed is in use (Chan, 2020; Silverman, 2017). Individuals could also place their shoes in opposite directions, with one shoe upside down. This is to confuse the spirits about the owners' 
whereabouts; additionally, it makes it harder for any spirits to put on the footwear and take control over the shoe-owner's body or life (Oei, 2013; Silverman, 2017; Thio, 2015; Woon, 2019; Yusof, 2015).

As for items in the room, it is believed that touching or moving holy books might adversely affect the protective powers (Woon, 2019). Thus, it is recommended to refrain from disturbing the items that are meant to keep the individuals safe (Silverman, 2017). It is also believed that an open umbrella indoors may lead to financial doom due to natural disasters or other misfortune. This could be why hotels choose to have umbrella holders outside their properties, for reasons beyond housekeeping purposes (eHotelier, 2019).

In the Chinese tradition, there are 'yin' and 'yang' places, referring to the dark and light portions of the universe respectively. As closets are sometimes musty, they are considered as 'yin' places where evil spirits may linger in and even wear the clothes (Silverman, 2017; Woon, 2019). Related to the 'yin' element, it is thought that spirits tend to gather in areas with less human traffic and energy, such as at the end of the hall or near to stairwell. To compensate for the inadequate amount of vitality, individuals who stay in such 'remote' rooms ought to make some noise, such as having music to increase the level of liveliness (Thio, 2015).

\section{Methodology \\ Research Design}

Two non-probability sampling techniques were utilised in this research, namely, snowballing and voluntary response sampling. Snowball sampling was selected because the sample that fits the characteristics of the targeted population is known to the researchers, and they are more readily and easily reachable than unknown individuals. This method also allowed the researchers to ensure that the sample possesses the heterogeneity elements of the population. Voluntary response sampling was used, having considered the nature of the study that involved the personal conduct of superstitious behaviours. Hence, individuals could voluntarily decide if they wanted to be included in the sample to indicate their responses.

The distribution of the survey was done in two ways: on a social media platform within online communities and via an online questionnaire platform, Qualtrics. Anyone who is at least 18 years old and fits the other criterion of being a guest at hotels, hostels, Airbnb, etc., could participate in the survey. The survey with an anonymous link was distributed between March and May 2021. The data collected will not be traced back to the respondents and no identifying information was collected.

\section{Questionnaire Design}

The questionnaire had three sections. The first section was designed to include some inclusion/ exclusion questions with the intention of recruiting the right group of people to maintain data reliability. It comprised the qualifying questions to ensure that the respondents fit the criteria of being guests at hotels, hostels, Airbnb, etc., and are at least 18 years old.

The second section consisted of various superstitions expressed in 18 statements (Table1) to contextualise superstitious behaviours, habits, and beliefs. The constructs encompassed numerology belief, room attributes, housekeeping nuances andsocial practices, which were sourced from various academic journals (e.g., Carlson et al., 2009; Dag, 1999; Delacroix \& Guillard, 2008; Pratt \& Kirillova, 2019) and informal sources such as websites that document these superstitious behaviours (e.g., Chan, 2020; De Lollis, 2007; Diamond, 2017; eHotelier, 2019; Oei, 2013; Prakash, 2016; Silverman, 2017; Thio, 2015; Woon, 2019).

The questionnaire items that operationalised the various constructs were measured on a five-point Likert scale ( $1=$ Strongly Disagree and $5=$ Strongly Agree) in the online survey format. The final section of the questionnaire collected demographical data of gender, age group, educational level, monthly income and religion. A pre-testing exercise was conducted on three individuals to check for awkward wording, ambiguous questions, leading questions or compound questions. Some minor re-rephrasing was subsequently done to increase the clarity. The entire survey was done anonymously, with no identifier to link back to the respondents.

\section{Data Analysis}

The dataset was checked for missing values, outliers, and other statistical issues that might affect 
the result. Internal consistency was also established, with Cronbach's Alpha score of .935.

To fulfil the first research aim of examining the variety of superstitions of accommodation guests based on their demographic, a descriptive statistic on the demographic was conducted to illustrate this. To achieve the second aim of uncovering the effects of demographics on superstitions, a one-way MANOVA analysis incorporating all 18 dependent variables of superstitious behaviourswas carried out with each independent variable(i.e., gender, age, educational level, monthly income and religion).

\section{Table 1: The 18 statements / questionnaire items}

Believe that certain numbers are lucky or unlucky.

Refuse to stay on a floor associated with an "unlucky" number.

Knock on the room door before entering.

Upon entering the room, open all the windows.

Upon entering the room, switch on all the lights.

Upon entering the room, draw open all the curtains.

Place random belongings or anything to occupy the unused bed.

Avoid placing hats on the bed.

Avoid sleeping in a room with a mirror facing the bed.

Cover all mirrors in the room before going to bed.

Make some noise if staying in a room located at the end of the hall or near the stairwell.

Not open an umbrella indoors.

Arrange shoes to point in different directions.

Arrange shoes so that one shoe is upside down.

Change a room if the Bible or any Holy scripture has been left open upon check-in.

Flush the toilet before the first usage.

Pat the pillow before going to bed.

Not hang up clothes in the closet.

\section{Demographic Analysis}

The eventual sample size of 126 has the demographics as shown in Table 2.

The respondents consist of more females $(63 \%$, $\mathrm{n}=80)$ than males $(37 \%, \mathrm{n}=46)$. Nearly half belong to the age group of 18 to 29 years old $(48 \%, n=60)$, which explains why $63 \%(n=79)$ of the entire sample have a monthly income of less than SGD $\$ 5,000$
(US\$3,800). The majority of the respondents are well educated, with $89 \%(n=113)$ holding an undergraduate degree or higher academic qualification. As for religion, most of them are either Buddhists (29\%, n=37), Christians (29\%, $n=36)$, or have no religion $(29 \%, n=37)$. The preferred accommodation type among the respondents is a hotel $(87 \%, n=110)$.

Table 2: Demographics

\begin{tabular}{llc}
\hline Gender & Female & $63 \%(\mathrm{n}=80)$ \\
& Male & $37 \%(\mathrm{n}=46)$ \\
Age & $18-29$ years old & $48 \%(\mathrm{n}=60)$ \\
& $30-39$ years old & $25 \%(\mathrm{n}=32)$ \\
& $40-49$ years old & $6 \%(\mathrm{n}=7)$ \\
& $50-59$ years old & $14 \%(\mathrm{n}=18)$ \\
& $60-69$ years old & $6 \%(\mathrm{n}=8)$ \\
Educational Level & 70 years old \& above & $1 \%(\mathrm{n}=1)$ \\
& Diploma & $6 \%(\mathrm{n}=7)$
\end{tabular}


KENG \& WEE, Journal of Business Strategy Finance and Management,

Vol. 03(1-2) 134-147 (2021)

\begin{tabular}{|c|c|c|}
\hline & Undergraduate Degree & $67 \%(n=85)$ \\
\hline & Master's Degree & $15 \%(n=19)$ \\
\hline & Doctoral Degree & $7 \%(n=9)$ \\
\hline & Others & $5 \%(n=6)$ \\
\hline \multicolumn{3}{|l|}{ Monthly Income } \\
\hline \multirow[t]{3}{*}{ (SGD = Singapore dollar) } & Under SGD $\$ 5,000$ (Under US\$3,800) & $63 \%(n=79)$ \\
\hline & SGD $\$ 5,001$ - $\$ 10,000$ (US\$3,801 - US\$7,500) & $29 \%(n=36)$ \\
\hline & Above SGD $\$ 10,000$ (Above US\$7,500) & $9 \%(n=11)$ \\
\hline \multirow[t]{5}{*}{ Religion } & Buddhism & $29 \%(n=37)$ \\
\hline & Christianity & $29 \%(n=36)$ \\
\hline & Islam & $3 \%(n=4)$ \\
\hline & No religion & $29 \%(n=37)$ \\
\hline & Others & $10 \%(n=12)$ \\
\hline \multirow[t]{2}{*}{ Preferred Accommodation } & Hotel & $87 \%(n=110)$ \\
\hline & Rented one (e.g., Airbnb) & $13 \%(n=16)$ \\
\hline
\end{tabular}

The mean scores show that there is no behaviour that both genders are more prone to doing when staying at accommodations (Table 3). No statement has a mean score that is above 4 (out of a maximum
5). While male and female respondents are equally inclined to knock on the room door before entering, they are similarly least likely to refrain from placing hats on beds.

Table 3: Mean scores (maximum 5) for superstitious behaviours based on gender

\begin{tabular}{lll}
\hline & Male & Female \\
\hline Believe that certain numbers are lucky or unlucky. & 3.07 & 3.20 \\
Refuse to stay on a floor associated with an "unlucky" number. & 2.26 & 2.36 \\
Knock on the room door before entering. & 3.54 & 3.81 \\
Upon entering the room, open all the windows. & 2.17 & 2.30 \\
Upon entering the room, switch on all the lights. & 3.33 & 3.74 \\
Upon entering the room, draw open all the curtains. & 2.98 & 3.24 \\
Place random belongings or anything to occupy the unused bed. & 2.26 & 2.57 \\
Avoid placing hats on the bed. & 1.96 & 1.93 \\
Avoid sleeping in a room with a mirror facing the bed. & 3.04 & 3.11 \\
Cover all mirrors in the room before going to bed. & 1.98 & 2.25 \\
Make some noise if staying in a room located at the end of the hall & 2.24 & 2.16 \\
or near the stairwell. & & \\
Not open an umbrella indoors. & 2.80 & 2.86 \\
Arrange shoes to point in different directions. & 2.17 & 2.70 \\
Arrange shoes so that one shoe is upside down. & 2.09 & 2.40 \\
Change a room if the Bible or any Holy scripture has been left & 2.17 & 2.21 \\
open upon check-in. & & 2.93 \\
Flush the toilet before the first usage. & 2.78 & 2.98 \\
Pat the pillow before going to bed. & 2.00 & 2.12 \\
Not hang up clothes in the closet. & &
\end{tabular}

There is no highlighted similarity or difference in behaviours between the younger and older respondents (Table 4). The only behaviour that has a relatively higher mean across all the age groups, especially for those who are 60 to 69 years old, is the switching on of all lights upon room entry. The 
two behaviours of knocking before entering room and drawing open the curtains have high scores across the age groups,except for those who are 40 to 49 years old and anyone who is above 70 years old, respectively.

Table 4: Mean scores (maximum 5) for superstitious behaviours based on age

\begin{tabular}{|c|c|c|c|c|c|c|}
\hline & $\begin{array}{l}18-29 \\
\text { yrs old }\end{array}$ & $\begin{array}{l}30-39 \\
\text { yrs old }\end{array}$ & $\begin{array}{l}40-49 \\
\text { yrs old }\end{array}$ & $\begin{array}{l}50-59 \\
\text { yrs old }\end{array}$ & $\begin{array}{l}60-69 \\
\text { yrs old }\end{array}$ & $\begin{array}{c}>70 \\
\text { yrs old }\end{array}$ \\
\hline Believe that certain numbers are lucky or unlucky. & 3.32 & 3.22 & 2.75 & 3.06 & 2.5 & 2.83 \\
\hline $\begin{array}{l}\text { Refuse to stay on a floor associated with an } \\
\text { "unlucky" number. }\end{array}$ & 2.4 & 2.07 & 2.50 & 2.53 & 2.13 & 2.17 \\
\hline Knock on the room door before entering. & 3.92 & 3.78 & 2.75 & 3.53 & 3.25 & 3.83 \\
\hline Upon entering the room, open all the windows. & 2.00 & 2.52 & 2.75 & 2.53 & 2.50 & 1.83 \\
\hline Upon entering the room, switch on all the lights. & 3.60 & 3.52 & 3.75 & 3.53 & 4.00 & 3.17 \\
\hline Upon entering the room, draw open all the curtains. & 3.05 & 3.04 & 4.13 & 3.41 & 3.25 & 2.33 \\
\hline $\begin{array}{l}\text { Place random belongings or anything to occupy } \\
\text { the unused bed. }\end{array}$ & 2.47 & 2.74 & 2.00 & 2.59 & 2.13 & 1.83 \\
\hline Avoid placing hats on the bed. & 1.77 & 2.26 & 1.75 & 2.18 & 2.00 & 1.67 \\
\hline Avoid sleeping in a room with a mirror facing the bed. & d. 3.20 & 3.04 & 2.75 & 2.76 & 3.00 & 3.67 \\
\hline Cover all mirrors in the room before going to bed. & 2.15 & 2.26 & 1.88 & 2.06 & 2.25 & 2.17 \\
\hline $\begin{array}{l}\text { Make some noise if staying in a room located at } \\
\text { the end of the hall or near the stairwell. }\end{array}$ & 2.13 & 2.33 & 2.38 & 2.18 & 2.38 & 1.67 \\
\hline Not open an umbrella indoors. & 3.13 & 2.78 & 2.25 & 2.65 & 2.13 & 2.50 \\
\hline Arrange shoes to point in different directions. & 2.77 & 2.52 & 1.63 & 2.53 & 1.75 & 2.00 \\
\hline Arrange shoes so that one shoe is upside down. & 2.52 & 2.19 & 1.88 & 2.24 & 1.75 & 1.83 \\
\hline $\begin{array}{l}\text { Change a room if the Bible or any Holy scripture } \\
\text { has been left open upon check-in. }\end{array}$ & 2.27 & 2.3 & 1.88 & 2.06 & 2.13 & 2.00 \\
\hline Flush the toilet before the first usage. & 3.05 & 2.85 & 2.25 & 3.29 & 3.25 & 2.17 \\
\hline Pat the pillow before going to bed. & 2.73 & 2.74 & 2.5 & 2.82 & 2.63 & 2.33 \\
\hline Not hang up clothes in the closet. & 1.93 & 2.30 & 1.75 & 2.29 & 2.38 & 2.00 \\
\hline
\end{tabular}

Table 5: Mean scores (maximum 5) for superstitious behaviours based on educational level

\begin{tabular}{|c|c|c|c|c|c|}
\hline & Diploma & $\begin{array}{l}\text { Under- } \\
\text { graduate }\end{array}$ & Master's & Doctoral & Others \\
\hline Believe that certain numbers are lucky or unlucky. & 2.71 & 3.18 & 3.53 & 2.67 & 2.83 \\
\hline $\begin{array}{l}\text { Refuse to stay on a floor associated with an } \\
\text { "unlucky" number. }\end{array}$ & 2.43 & 2.28 & 2.58 & 2.00 & 2.50 \\
\hline Knock on the room door before entering. & 3.14 & 3.98 & 3.26 & 2.44 & 4.00 \\
\hline Upon entering the room, open all the windows. & 2.14 & 2.27 & 2.37 & 1.89 & 2.33 \\
\hline Upon entering the room, switch on all the lights. & 4.14 & 3.68 & 3.42 & 2.44 & 3.83 \\
\hline Upon entering the room, draw open all the curtains. & 2.71 & 3.24 & 3.32 & 2.56 & 2.67 \\
\hline $\begin{array}{l}\text { Place random belongings or anything to occupy } \\
\text { the unused bed. }\end{array}$ & 2.14 & 2.60 & 2.32 & 2.00 & 2.00 \\
\hline Avoid placing hats on the bed. & 1.71 & 1.93 & 2.21 & 1.67 & 1.83 \\
\hline Avoid sleeping in a room with a mirror facing the bed. & 2.29 & 3.25 & 2.74 & 2.67 & 3.5 \\
\hline Cover all mirrors in the room before going to bed. & 1.71 & 2.25 & 2.00 & 2.00 & 2.00 \\
\hline Make some noise if staying in a room located at the & 1.71 & 2.29 & 2.05 & 2.11 & 1.83 \\
\hline
\end{tabular}


end of the hall or near the stairwell.

Not open an umbrella indoors.

\subsection{7}

1.86

Arrange shoes to point in different directions.

Arrange shoes so that one shoe is upside down.

Change a room if the Bible or any Holy scripture

has been left open upon check-in.

Flush the toilet before the first usage.

Pat the pillow before going to bed.

Not hang up clothes in the closet.
1.86

1.71

2.86

2.14

1.86

\subsection{6}

2.75

2.51

2.27

2.79

2.11

2.00

2.00

1.79

1.78

2.00

2.26

1.67

2.33

$\begin{array}{llll}3.06 & 2.95 & 2.33 & 2.67 \\ 2.71 & 2.84 & 2.89 & 2.67 \\ 2.19 & 1.79 & 1.78 & 2.17\end{array}$

The two behaviours of switch on all the lights upon room entry and knocking before entering the room have high scores across the educational levels, except for respondents with a doctoral degree. Those with master's degree also tend to do that, in addition to having the highest inclination to believe that certain numbers are lucky or unlucky. While respondents with a doctoral degree are less prone

to doing most of the superstitious behaviours as compared to the other groups with lower educational levels, they are relatively more neutral (and disagree less) about the patting of pillows before going to bed. The one superstitious behaviour that is least likely to be done by all respondents across educational levels is covering all mirrors in the room before going to sleep for the night (Table 5).

Table 6: Mean scores (maximum 5) for superstitious behaviours based on monthly income

\begin{tabular}{|c|c|c|c|}
\hline & $\begin{array}{l}\text { SGD } \$ 5,000 \\
<U S \$ 3,800)\end{array}$ & $\begin{array}{c}\text { SGD } \$ 5,001 \text { - } \\
\text { SGD } \$ 10,000 \\
\text { (US } \$ 3,801 \text { - } \\
\text { US } \$ 7,500)\end{array}$ & $\begin{array}{c}>\$ 10,000 \\
(>\text { US } \$ 7,500)\end{array}$ \\
\hline Believe that certain numbers are lucky or unlucky. & 3.35 & 2.87 & 2.69 \\
\hline Refuse to stay on a floor associated with an "unlucky" number. & 2.39 & 2.16 & 2.31 \\
\hline Knock on the room door before entering. & 3.90 & 3.32 & 3.56 \\
\hline Upon entering the room, open all the windows. & 2.30 & 2.29 & 1.94 \\
\hline Upon entering the room, switch on all the lights. & 3.71 & 3.45 & 3.25 \\
\hline Upon entering the room, draw open all the curtains. & 3.23 & 3.23 & 2.56 \\
\hline Place random belongings or anything to occupy the unused bed & ed. 2.67 & 2.16 & 2.00 \\
\hline Avoid placing hats on the bed. & 2.01 & 1.84 & 1.75 \\
\hline Avoid sleeping in a room with a mirror facing the bed. & 3.15 & 3.00 & 2.94 \\
\hline Cover all mirrors in the room before going to bed. & 2.18 & 2.29 & 1.75 \\
\hline $\begin{array}{l}\text { Make some noise if staying in a room located at the end of } \\
\text { the hall or near the stairwell. }\end{array}$ & 2.28 & 2.16 & 1.81 \\
\hline Not open an umbrella indoors. & 3.14 & 2.48 & 2.06 \\
\hline Arrange shoes to point in different directions. & 2.71 & 2.16 & 2.19 \\
\hline Arrange shoes so that one shoe is upside down. & 2.48 & 2.06 & 1.75 \\
\hline $\begin{array}{l}\text { Change a room if the Bible or any Holy scripture has been } \\
\text { left open upon check-in. }\end{array}$ & 2.39 & 1.84 & 1.94 \\
\hline Flush the toilet before the first usage. & 3.11 & 2.74 & 2.63 \\
\hline Pat the pillow before going to bed. & 2.91 & 2.29 & 2.5 \\
\hline Not hang up clothes in the closet. & 2.11 & 1.94 & 2.19 \\
\hline
\end{tabular}

Those with a monthly income under Singapore $\$ 5,000$ (US $\$ 3,800$ ) are most likely to knock on the room door before entering and switching on all the lights. The next group with a higher monthly income of Singapore 5,0001 to $\$ 10,000$ (US $\$ 3,801$ to $\$ 7,500$ ) has the same inclinations to perform 
these two behaviours, albeit with a slightly lower mean scores. Those who earn more than Singapore $\$ 10,000$ (US $\$ 7,500$ ) a month are also most likely to knock on the room door before entering. However, this group with the highest monthly income is comparatively less inclined than the other groups in a few behavioural aspects, such as not placing hats on the bed, covering all mirrors in the room before going to bed, or arranging shoes so that one shoe is upside down (Table 6).

Table 7: Mean scores (maximum 5) for superstitious behaviours based on religion

\begin{tabular}{|c|c|c|c|c|c|}
\hline & Buddhisn & Christianity & Islam & $\begin{array}{l}\text { No } \\
\text { religion }\end{array}$ & Others \\
\hline Believe that certain numbers are lucky or unlucky. & 3.59 & 2.64 & 2.00 & 3.3 & 3.25 \\
\hline $\begin{array}{l}\text { Refuse to stay on a floor associated with an } \\
\text { "unlucky" number. }\end{array}$ & 2.57 & 1.94 & 1.50 & 2.41 & 2.75 \\
\hline Knock on the room door before entering. & 4.41 & 2.86 & 2.25 & 3.84 & 4.25 \\
\hline Upon entering the room, open all the windows. & 2.49 & 1.89 & 3.00 & 2.24 & 2.42 \\
\hline Upon entering the room, switch on all the lights. & 3.84 & 3.39 & 4.25 & 3.38 & 3.83 \\
\hline Upon entering the room, draw open all the curtains. & 3.57 & 2.94 & 3.50 & 2.84 & 3.25 \\
\hline $\begin{array}{l}\text { Place random belongings or anything to occupy } \\
\text { the unused bed. }\end{array}$ & 2.81 & 2.08 & 1.75 & 2.32 & 3.17 \\
\hline Avoid placing hats on the bed. & 2.22 & 1.67 & 1.25 & 1.89 & 2.25 \\
\hline Avoid sleeping in a room with a mirror facing the bed. & 3.43 & 2.75 & 2.25 & 2.95 & 3.75 \\
\hline Cover all mirrors in the room before going to bed. & 2.51 & 1.89 & 2.00 & 2.03 & 2.25 \\
\hline $\begin{array}{l}\text { Make some noise if staying in a room located at the. } \\
\text { end of the hall or near the stairwell }\end{array}$ & 2.49 & 1.92 & 1.50 & 2.16 & 2.42 \\
\hline Not open an umbrella indoors. & 3.57 & 2.50 & 1.25 & 2.54 & 3.08 \\
\hline Arrange shoes to point in different directions. & 3.30 & 1.75 & 1.00 & 2.38 & 3.25 \\
\hline Arrange shoes so that one shoe is upside down. & 2.86 & 1.61 & 1.25 & 2.27 & 2.92 \\
\hline $\begin{array}{l}\text { Change a room if the Bible or any Holy scripture has } \\
\text { been left open upon check-in. }\end{array}$ & 2.62 & 1.81 & 1.50 & 2.05 & 2.75 \\
\hline Flush the toilet before the first usage. & 3.51 & 2.56 & 1.75 & 2.81 & 3.33 \\
\hline Pat the pillow before going to bed. & 3.14 & 2.33 & 2.25 & 2.57 & 3.08 \\
\hline Not hang up clothes in the closet. & 2.43 & 1.78 & 1.25 & 2.05 & 2.25 \\
\hline
\end{tabular}

For all religious groups, they are more prone to switch on all the lights upon room entry, among the 18 behaviours. For respondents who choose Buddhism or other religions, they have a high tendency to knock on the room door before entering, with mean scores of 4.41 and 4.25 , respectively. Even those who have no religion show inclination to knock on the door before entry and turn on all lights after entry. As compared to respondents with other religious affiliations, the respondents who choose Islam are relatively more likely to turn on all the lights; they are also relatively less likely to perform 15 out of 18 behaviours, especially arranging shoes to point in different directions that has a mean score of 1 (Table 7 ).
As a summary, the two behaviours of knocking on the room door before entering and turning on all lights after entering have a mean score of more than 3 for all demographical variables (Table 8). The demographical variable of gender has more affirmative responses to more behavioural statements, including the belief in a lucky or unlucky number and not sleeping in a room with the mirror facing the bed. The demographical variable of age also shows responses to behaviours such as drawing open all curtains upon room entry. The majority of the mean scores are less than 3 , implying that the sample in this study is generally not prone to displaying most of the superstitious behaviours. 
KENG \& WEE, Journal of Business Strategy Finance and Management,

Vol. 03(1-2) 134-147 (2021)

Table 8: Mean scores (maximum 5) of superstitious behaviours

based on demographical variables

\begin{tabular}{|c|c|c|c|c|c|}
\hline & Gender & Age & $\begin{array}{l}\text { Educational } \\
\text { Level }\end{array}$ & $\begin{array}{l}\text { Monthly } \\
\text { Income }\end{array}$ & Religion \\
\hline Believe that certain numbers are lucky or unlucky. & $>3$ & $<3$ & $<3$ & $<3$ & $<3$ \\
\hline $\begin{array}{l}\text { Refuse to stay on a floor associated with an } \\
\text { "unlucky" number. }\end{array}$ & $<3$ & $<3$ & $<3$ & $<3$ & $<3$ \\
\hline Knock on the room door before entering. & $>3$ & $>3$ & $>3$ & $>3$ & $>3$ \\
\hline Upon entering the room, open all the windows. & $<3$ & $<3$ & $<3$ & $<3$ & $<3$ \\
\hline Upon entering the room, switch on all the lights. & $>3$ & $>3$ & $>3$ & $>3$ & $>3$ \\
\hline Upon entering the room, draw open all the curtains. & $<3$ & $>3$ & $<3$ & $<3$ & $<3$ \\
\hline $\begin{array}{l}\text { Place random belongings or anything to occupy } \\
\text { the unused bed. }\end{array}$ & $<3$ & $<3$ & $<3$ & $<3$ & $<3$ \\
\hline Avoid placing hats on the bed. & $<3$ & $<3$ & $<3$ & $<3$ & $<3$ \\
\hline Avoid sleeping in a room with a mirror facing the bed. & $>3$ & $<3$ & $<3$ & $<3$ & $<3$ \\
\hline Cover all mirrors in the room before going to bed. & $<3$ & $<3$ & $<3$ & $<3$ & $<3$ \\
\hline $\begin{array}{l}\text { Make some noise if staying in a room located at the } \\
\text { end of the hall or near the stairwell. }\end{array}$ & $<3$ & $<3$ & $<3$ & $<3$ & $<3$ \\
\hline Not open an umbrella indoors. & $<3$ & $<3$ & $<3$ & $<3$ & $<3$ \\
\hline Arrange shoes to point in different directions. & $<3$ & $<3$ & $<3$ & $<3$ & $<3$ \\
\hline Arrange shoes so that one shoe is upside down. & $<3$ & $<3$ & $<3$ & $<3$ & $<3$ \\
\hline $\begin{array}{l}\text { Change a room if the Bible or any Holy scripture has } \\
\text { been left open upon check-in. }\end{array}$ & $<3$ & $<3$ & $<3$ & $<3$ & $<3$ \\
\hline Flush the toilet before the first usage. & $<3$ & $<3$ & $<3$ & $<3$ & $<3$ \\
\hline Pat the pillow before going to bed. & $<3$ & $<3$ & $<3$ & $<3$ & $<3$ \\
\hline Not hang up clothes in the closet. & $<3$ & $<3$ & $<3$ & $<3$ & $<3$ \\
\hline
\end{tabular}

To further confirm how demographics might have affected superstitions, a one-way MANOVA analysis was conducted. The results indicated no statistically significant difference in superstitious behaviours for all variables.

Table 9: One-way MANOVA for demographics

\begin{tabular}{lcccc}
\hline & \multicolumn{1}{c}{ Effect } & Value & Significance & Partial $\mathbf{n}$ \\
\hline Gender & Wilks' Lambda & 0.887 & 0.740 & 0.113 \\
Age & Wilks' Lambda & 0.408 & 0.201 & 0.164 \\
Educational level & Wilks' Lambda & 0.538 & 0.538 & 0.144 \\
Monthly Income & Wilks' Lambda & 0.687 & 0.198 & 0.171 \\
Religion & Wilks' Lambda & 0.478 & 0.165 & 0.169 \\
\hline
\end{tabular}

For demographical variables such as gender, age, education, income, and religion, the $p$-value is more than .05; Wilk's $\wedge$ for gender $=0.887$, age $=0.408$, educational level $=0.538$, monthly income $=0.687$, and religion $=0.478$ respectively. The partial $\eta 2$ ranges between .113 to .171 , which again indicated that the results lack any significant effects. In other words, none of the five demographical variables affects superstitious behaviours (Table 9).

\section{Discussion}

Past research highlighted that gender, age, education, economic status, and religion could affect superstitious behaviours. However, the results from 
this study reveal that demographical variables do not have much effect on superstitious behaviours. There are only minimal differences in certain behaviours observed across the demographical variables, such as the knocking on the room door and the switching on of all lights. This suggests that the respondents may still be somewhat superstitious but to a small extent. If demographics do not impact superstitious behaviours, then what could be some other influencing factors? There were suggestions that superstitious behaviours might be due to individuals' acquiescence to follow common intuitions (Risen, 2016) or the desire to have a sense of control over phenomena (Dagnall \& Drinkwater, 2018).

Notwithstanding the results from this study, it is still commercially warranting for accommodation operators to observe, respect, and respond to any of their guests' superstitions. For example, operators could plan room design to include a master switch at the door entrance to turn on all the lights or avoid placing a mirror facing the bed. Afterall, respecting guests' subtle superstitious inclinations is part of service and customer value creation.

For future research, a different sampling could perhaps be adopted. This study did not follow the basic tenets of inferential statistical analyses and had instead employed the usage of a non-probability sampling method (purpose sampling). For future studies, the use of probability sampling from a target population (for instance, hotel guest lists) could reflect a different set of insights into this topic of superstitious behaviours.
Alternatively, a broader measure of superstition types that includes more forms and diversity could be another direction for future research. For example, region-specific superstitions could be explored so as to increase the applicability of results to a particular geographical or cultural setting. In addition, psychological aspects (such as the sense of control that is mentioned earlier in the discussion section) are other measures that could be examined.

\section{Concluding Remarks}

Superstitions are part of any culture, all over the world. Despite their prevalence, there is little research that was conducted on this topic for the accommodation industry sector. It is an area of study that could be investigated more systematically as accommodation operators have to be culturally sensitive and respectful of guests' personal beliefs and behaviours. Meeting guests' superstition-related requests is simply a part of service management.

\section{Acknowledgement}

This research received no specific grant from any funding agency in the public, commercial, or notfor-profit sectors.

\section{Funding}

The authors received no financial support for the research, authorship, and/or publication of this article.

\section{Conflict of Interest}

The authors reported no potential competing interests.

\section{References}

1. Aarnio, K., \& Lindeman, M. (2005). Paranormal beliefs, education, and thinking styles. Personality and Individual Differences, 39(7), 1227 -1236. https://doi.org /10.1016/j. paid.2005.04.009.

2. Abitov, I., Gorodetskaya, I., Akbirova, R., \& Sibgatullina, L. (2018). Superstitiousness and paranormal beliefs of engineering students comparing to students majoring in sciences, arts and humanities. Espacios, 39(10), 28.

3. Abrams, D., Hinkle, S., \& Tomlins, M. (1999). Leaving Hong Kong? The roles of attitude, subjective norm, perceived control, social identity and relative deprivation. International Journal of Intercultural Relations, 23(2), 319 -338. https://doi.org/10.1016/S01471767(98)00041-8.

4. Barro, R. J., \& McCleary, R. M. (2002). Religion and Political Economy in an International Panel. NBER Working Papers 8931, National Bureau of Economic Research, Inc.https://doi. org/10.3386/w8931

5. Burakov, D. (2018). Do discounts mitigate numerological superstitions? Evidence from 
the Russian real estate market. Judgment and Decision Making, 13(5), 467 -470.https://Econ Papers.repec.org/RePEc:jdm:journl:v:13:y:20 18:i:5:p:467-470.

6. Burger, J. M. (1989). Negative reactions to increases in perceived personal control. Journal of Personality and Social Psychology, 56(2), 246-256. https://doi.org/10.1037/00223514.56.2.246.

7. Carlson, B., Mowen, J., \& Fang, X. (2009). Trait superstition and consumer behavior: reconceptualisation, measurement, and initial investigations. Psychology and Marketing, 26(8), 689 - 713. https://doi.org/10.1002/ mar.20295.

8. Carroll, J. (2007). Thirteen percent of Americans bothered to stay on hotels' $13^{\text {th }}$ floor. https:// news.gallup.com/poll/26887/thirteen-percentamericans-bothered-stay-hotels-13th-floor. aspx.

9. Case, T.I., Fitness, J., Cairns, D.R., \&Stevenson, R.J. (2004). Coping with uncertainty: superstitious strategies and secondary control. Journal of Applied Social Psychology, 34(4), 848-871. https://doi. org/10.1111/j.1559-1816.2004.tb02574.x.

10. Chakraborty, S. (2017). A comparative analysis of superstitious beliefs existing among college students. International Journal of Educational Science and Research, 7(6), 57-66. https://doi. org/10.24247/ijesrdec20177.

11. Chan, M. (2020).13 weird travel superstitions from all over the world. https://explore.traveloka. com/features/weird-travel-superstitions.

12. Dag, I. (1999). The relationships among paranormal beliefs, locus of control and psychopathology in a Turkish college sample. Personality and Individual Differences, 26, 723-737.https://doi.org/10.1016/S01918869(98)00184-6.

13. Dagnall, N., \& Drinkwater, K. (June 2, 2018). The science of superstition - and why people believe in the unbelievable. https://theconversation. com/the-science-of-superstition-and-whypeople-believe-in-the-unbelievable-97043.

14. Delacroix, E., \& Guillard, V. (2008). Understanding, defining and measuring the trait of superstition, Selected Proceedings of the IAREP/SABE 2008 Conference at LUISS in Rome, Luiss University Press: Rome. https:// www.researchgate.net/publication/41221415_
Understanding_defining_and_measuring_the_ trait_of_superstition.

15. De Lollis, B. (2007). Some hotels now include floor no. 13. Hartford Business. https://www. hartfordbusiness.com/article/some-hotels-nowinclude-floor-no-13.

16. Diamond, M. (2017). 20 bizarre superstitions from around the world and the meaning behind them. https://www.businessinsider.com/ superstitions-around-the-world-2017-9.

17. eHotelier (2019). Top 5 weird superstitions hotels have to deal with.https://insights. ehotelier.com/insights.

18. Ellis, L. (1988). Religiosity and superstition: Are they related or separate phenomena? Psychology: A Journal of Human Behavior, 25(2), 12-13.

19. Emmons, C. F.,\& Sobal, J. (1981). Paranormal beliefs: testing the marginalityhypothesis. Sociological Focus, 14(1), 49- 56). https://doi. org/10.1080/00380237.1981.10570381.

20. Gere, J.,\& Macdonald, G. (2010). An update of the empirical case for the need to belong. Journal of Individual Psychology, 66(1), 93-115.

21. Gmelch, G. (1972). Baseball in Professional Baseball. In G. P. Stone (Ed.),Games, Sport and Power, Transaction(pp.128-137).Dutton.

22. Goode, E. (2000). Two paranormalisms or two and a half? An empirical exploration. Skeptical Inquirer, 24(1), 29-35.https://cdn. centerforinquiry.org/wp-content/uploads/ sites/29/2000/01/22164900/p29.pdf.

23. Hagan, J. E., Schack, T., \& Schinke, R. (2019). Sport psychology practice in Africa: Do culture-specific religion and spirituality matter? Advances in Social Sciences Research Journal, 6(3). https://doi.org/10.14738/assrj.63.6209.

24. Hood, B. (2010). The Science of Superstition: How the Developing Brain Creates Supernatural Beliefs. HarperCollins.

25. Huang, L.,\& Teng, C. (2009). Development of a Chinese superstitious belief scale. Psychological reports,104, 807-819. https://doi.org/10.2466/ PR0.104.3.807-819.

26. Jirásek, I. (2018). Religion and Spirituality in Sport. Oxford Research Encyclopedia of Psychology. https://doi.org/10.1093/ acrefore/9780190236557.013.149.

27. Kramer, T.,\& Block, L. (2011). Nonconscious effects of peculiar beliefs on consumer psychology and choice. Journal of Consumer 
Psychology, 21(1), 101-111.

28. MacDonald, W. (1995). The effects of religiosity and structural strain on reported paranormal experiences. Journal for the Scientific Study of Religion, 34(3), 366-376. https://doi. org/10.2307/1386885.

29. Marchetti, S. (2020). 10 ways to jinx yourself in Italy (and the one way to reverse it). https://www. fodors.com/world/europe/italy/experiences/ news/10-ways-to-jinx-yourself-in-italy-and-theone-way-to-reverse-it.

30. McCartney, S. (2013). The oddest airline superstitions. https://www.wsj.com/articles/ the-oddest-airline-superstitions-1380754239.

31. Mowen, J.C.,\& Carlson, B. (2003). Exploring the antecedents and consumer behavior consequences of the trait of superstition. Psychology \& Marketing, 20,1045 -1065. https:// doi.org/10.1002/mar.10108.

32. Mulvania, A. (n.d.). Google Arts \& Culture. 18 superstitions from around the world. https://artsandculture.google.com/story/18superstitions-from-around-the-world/ QQlyTWmzJ9QvLg.

33. Oei, M. (2013). Do you believe in any of these 9 hotel superstitions?https://says.com/my/ lifestyle/hotel-room-superstitions.

34. Orenstein, A. (2002). Religion and paranormal belief. Journal for the Scientific Study of Religion, 41(2), 301-311. https://doi.org/10.1111/14685906.00118.

35. Prakash, A. (2016). The Most Bizarre Travel Superstitions Around The World. https:// www.news.com.au/travel/travel-updates/ travel-stories/the-most-bizarre-travelsuperstitions-around-the-world/news-story/ efab11d306dc556d9894f1c6e6192cf1.

36. Pratt, S., \& Kwan, P. (2019). Unlucky for some? Are some hotel rooms and floors really unluckier than others? International Journal of Culture, Tourism, and Hospitality Research, 13(1), 70-83. https://doi.org/10.1108/ IJCTHR-06-2018-0082.

37. Pratt, S.,\& Kirillova, K. (2019). Are hotel guests bothered by unlucky floor or room assignments? International Journal of Hospitality Management, 83, 83 - 94.https:// doi.org/10.1016/j.jjhm.2019.03.024

38. Raesita, K., \&Mahadwartha, P. A. (2020). Superstitions and Price Clustering in the Taiwan Stock Exchange. 115(Insyma), 483-488. https:// doi.org/10.2991/aebmr.k.200127.097.

39. Reisinger, Y.,\&Mavondo,F. T. (2005). Travel anxiety and intentions to travel internationally: implications of risk perception. Journal of Travel Research, 43(3), 212-225. https://doi. org/10.1177/0047287504272017.

40. Rice, T.W. (2003). Believe it or not: religious and other paranormal beliefs in the United States. Journal for the Scientific Study of Religion, 42, 95- 106. https://doi.org/10.1111/14685906.00163.

41. Risen, J. L. (2016). Believing what we do not believe: Acquiescence to superstitious beliefs and other powerful intuitions. Psychological review, 123(2), 182-207. https://doi. org/10.1037/rev0000017.

42. Romero, K. (2016). From avoiding the 4th floor to sacrificing a goat: travel superstitions around the world. https://www.express.co.uk/travel/ articles/634254/Travel-superstitions-aroundthe-world-pictures.

43. Salter, C. A.,\& Routledge, L. M. (1971). Supernatural beliefs among graduate students at the University of Pennsylvania. Nature 232, 278-279. https://doi.org/10.1038/232278a0

44. Silverman, S. (10 June 2017). 10 Chinese Travel Superstitions. https://www.digmandarin. com/chinese-travel-superstitions.html.

45. Simmons, L., \& Robert, S. (2003). Cultural superstitions and price-endings. Journal of International Marketing, 11(2), 101-111. http:// www.jstor.org/stable/25048935.

46. Smith, H. J., Pettigrew, T. F., Pippin, G.M.,\&Bialosiewicz, S. (2012). Relative deprivation: atheoretical and meta-analytic review. Personality and Social Psychology Review, 16(3), 203-232. https://doi.org $/ 10.1177 / 1088868311430825$.

47. Stark, R.,\&Bainbridge, W. S. (1980). Networks of faith: interpersonal bonds and recruitment to cults and sects. American Journal of Sociology, 85(6), 1376-1395.http://www.jstor. org/stable/2778383.

48. Sun, J. (2014). How risky are services? An empirical investigation on the antecedents and consequences of perceived risk for hotel service. International Journal of Hospitality Management, 37, 171-179. https://doi. org/10.1016/j.ijhm.2013.11.008

49. Thio, B. (2015). 6 bizarre hotel superstitions you'll pick up while traveling. https://roamscapes. 
com/crazy-hotel-superstitions.

50. Tobacyk, J.,\& Milford, G. (1983). Belief in paranormal phenomena: assessment instrument development and implications for personality functioning. Journal of Personality and Social Psychology, 44(5), 1029-1037. https://doi.org/10.1037/0022-3514.44.5.1029.

51. Torgler, B. (2003). It Is About Believing: Superstition and Religiosity.CREMA Working Paper Series 2003-10, Center for Research in Economics, Management and the Arts (CREMA).

52. Torgler, B. (2007). Determinants of superstition. Journal of Socio-Economics, 36(5), 713-733. https://doi.org/10.1016/j.socec.2007.01.007.

53. Undie, U. J., \& Ushie, B. A. (2018). Influence of sex and superstitious beliefs on Pupils academic performance in the early years'science in south eastern Nigeria. International Journal of Education and Evaluation, 4(3), 45-55.ISSN 2489-0073.

54. University of Chicago Booth School of Business (2015), The power of magical thinking: Why superstitions are hard to shake. https://www.sciencedaily.com/ releases/2015/11/151109160450.htm.

55. Valussi, E. (2020). Men built religion, and women made it superstitious: gender and superstition in Republican China. Journal of Chinese Religions, 48(1), 87 -125.https://www. muse.jhu.edu/article/754049.

56. Vaidyanathan, R., Aggarwal, P., \&Bakpayev, M. (2018). A functional motivational framework for examining superstitious behavior. Journal of the Association for Consumer Research,3(4), 454-465.

57. Victor, C. R.,\&Yang, K. (2012). The prevalence of loneliness among adults: a case study of the United Kingdom. Journal of Psychology, 146(1-2), 85-104. https://doi.org/10.1080/002 23980.2011.613875.

58. Vyse, S. (2014). Believing in magic: The psychology of superstition. Oxford University Press.

59. Wang, D., Oppewal, H., \& Thomas, D. (2014). Exploring attitudes and affiliation intentions toward consumers who engage in socially shared superstitious behaviors: a study of students in the east and the west. Psychology and Marketing, 31(3), 203 - 213. https://doi. org/10.1002/mar.20687.

60. Wiseman, R., \& Watt, C. (2004). Measuring superstitious belief: Why lucky charms matter. Personality and Individual Differences, 37(8), 1533 - 1541. https://doi.org/10.1016/j. paid.2004.02.009.

61. Wolfradt, U. (1997). Dissociative experiences, trait anxiety and paranormal beliefs. Personality and Individual Differences, 23(1),15-19.https:// doi.org/10.1016/S0191-8869(97)00043-3.

62. Woon, G. (2019). 8 'travel superstitions' your Asian mom probably warned you about. https:// www.tripzilla.com/8-travel-superstitions-yourasian-mom-probably-warned-you-about/97532.

63. Wu, W. T., Chen, C. B., \& Chang, C. C. (2016). While number superstitions exist: the influence of prices on mobile phone consumers' purchase intentions. Journal of Mass Communication and Journalism, 6(3), 1-5. https://doi:10.4172/2165-7912.1000304.

64. Yang, E. C. L., Khoo-Lattimore, C., \&Arcodia, C. (2018). Power and empowerment: how Asian solo female travellers perceive and negotiate risks. Tourism Management, 68, 32-45. https:// doi.org/10.1016/j.tourman.2018.02.017.

65. Yusof, S. (2015). Secret superstitions: things the hotel staff won't tell you. https://wanderluxe. theluxenomad.com/things-the-hotel-staff-wonttell-you.

66. Zinnbauer, B., Pargament, K., Cole, B., Rye, M., Butter, E., Belavich, T., ... Kadar, J. (1997). Religion and spirituality: unfuzzying the fuzzy. Journal for the Scientific Study of Religion, 36(4), 549-564. https://doi.org/10.2307/1387689. 